\title{
Expression of Cyclin-Dependent Kinase 6 (cdk6) and Frequent Loss of CD44 in Nasal-Nasopharyngeal NK/T-Cell Lymphomas: Comparison with CD56-Negative Peripheral T-Cell Lymphomas
}

\author{
Huang-Chun Lien, Chun-Wu Lin, Pei-Hsin Huang, Min-Lee Chang, and \\ Su-Ming Hsu
}

Department of Pathology, National Taiwan University Hospital, National Taiwan University College of Medicine, Taipei, Taiwan

\begin{abstract}
SUMMARY: Lymphomas involving the nasal and nasopharyngeal region mainly include CD56-positive natural killer (NK)/T-cell lymphomas, CD56-negative peripheral T-cell lymphomas (PTL), and B-cell lymphomas. Among these, the CD56-positive lymphoma, presumably of an NK/T-cell nature, is frequently seen in Asian, Mexican, and South American patients. NK cells are proposed to be closer developmentally to $T$ cells than to other lymphoid cells, because bipotential common progenitor cells of NK/T-cell lineage have been isolated. In this study, we collected 47 cases of nasal lymphoma and investigated the phenotypic difference between NK/T-cell lymphoma and PTL by examining the pattern of the developmentally differentially expressed molecules cdk6 (cyclin-dependent kinase 6), CD44, CD117, and by examining the rearrangement of the T-cell receptor gene (TcR-GR). cdk6, an essential regulator of the cell cycle in $\mathrm{G}_{1}$ progression, was over-expressed in a subset of cortical thymocytes, but absent in mature thymocytes. In contrast, CD44, a glycosylated adhesion molecule, was absent in cortical thymocytes, but present in mature thymocytes and peripheral activated T cells. We found both over-expression of nuclear cdk6 ( $\mathrm{n}-\mathrm{cdk6}$ ) and frequent absence of CD44 in nasal CD56-positive NK/T-cell lymphomas, in contrast to most nasal CD56-negative PTL, which were CD44-immunoreactive with weak or no expression of n-cdk6. Almost all tested cases of NK/T-cell lymphoma displayed a germ-line configuration of $T c R$, without evidence of gene rearrangement. Thus, there seems to be a useful distinction between

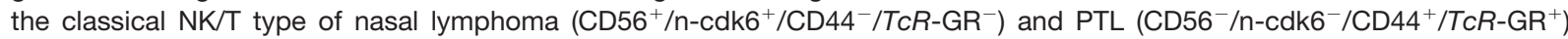
involving the nasal region. The presence of Epstein-Barr virus does not seem to be a good marker for distinguishing between NK/T lymphoma and PTL involving the nasal region. (Lab Invest 2000, 80:893-900).
\end{abstract}

$P$ sing rimary CD56-positive non-Hodgkin's lymphoma of the nose and nasopharynx (NNP-NHL) is rare in Western populations, but occurs rather commonly among Asians, Mexicans, and South Americans (Arber et al, 1993; Chan et al, 1987; Ho et al, 1984; Jaffe et al, 1996). The disease usually is characterized by progressive, unrelenting ulceration and necrosis of the nasal cavity and midline facial tissues (Jaffe et al, 1989). The involved tissues display features of pleomorphic tumor cells that are variably associated with angiocentric and angiodestructive growth as well as zonal coagulative necrosis. Thus, the lesions have been designated by terms such as midline lethal granuloma, polymorphic reticulosis, or angiocentric lymphoma, reflecting the unique features of the tumors (Ho et al, 1990a Jaffe et al, 1996).

NNP-NHL has been regarded a special subset of peripheral T-cell lymphomas (PTL) because of the expression of selected T-cell-related antigens (ie,

Received January 21, 2000.

Address reprint requests to: Dr. S.-M. Hsu, Department of Pathology, National Taiwan University College of Medicine, 1-1 Jen-Ai Road, Taipei, Taiwan 106.
CD2, CD43, and/or CD45RO) (Chan et al, 1987). However, the usual absence of other T-lineage antigens, such as CD4, CD5, CD8, and surface CD3 (Chan et al, 1987; Jaffe et al, 1996), the frequent presence of germ-line T-cell receptor (TcR) genes (Ho et al, 1990a; Jaffe et al, 1996), and, in most cases, the expression of a natural killer (NK)-cell marker, CD56 (Ho et al, 1990a; Jaffe, 1995, 1996; Kanavaros et al, 1993; Suzumiya et al, 1994), raise doubts about the true nature of this lymphoma. The term "nasal T/NK-cell lymphoma" was proposed in 1994 to reflect the existence of the characteristics of both $\mathrm{T}$ cells and NK cells (Jaffe et al, 1996). The nasal T/NK-cell lymphoma cells may contain azurophilic granules and may express cytotoxic granule-associated proteins such as perforin and granzyme B (Elenitoba-Johnson et al, 1998; Mori et al, 1996; $\mathrm{Ng}$ et al, 1997), typical for NK cells. However, nasal T/NK-cell lymphoma cells generally lack mature NK-cell markers, such as CD16 and CD57 (Jaffe et al, 1996). Some studies have suggested that the $\mathrm{CD}^{+}{ }^{+}$nasal lymphomas may be a mixed entity comprised of bona-fide NK-cell lymphomas together with a small number of true T-cell lymphomas (Chiang et al, 1996, 1997; Jaffe, 1995). 
It is not always possible to make morphologic and phenotypic distinctions between NK/T-cell lymphomas and PTL because of their frequent overlapping features. For example, angioinvasion, characteristic of $\mathrm{NK} / \mathrm{T}$-cell lymphomas, is seen in only $64 \%$ of these cases (Jaffe et al, 1996). The presence of CD56, although currently regarded a marker for NK/T-cell lymphoma, is not diagnostic of this NK Iymphoma, because some PTL may be CD56 ${ }^{+}$(Emile et al, 1996). Furthermore, CD56 is usually but not always positive in NK/T-cell lymphomas. A combined genotype of germ-line $T c R$ is mandatory for the diagnosis of $\mathrm{NK} /$ T-cell lymphoma, but rare cases with clonal gene rearrangement have also been reported (Gaulard et al, 1988; Ho et al, 1990a; 1990b; Kanavaros et al, 1993). Despite the lack of specific markers, a combination of morphology; phenotypic features such as the presence of CD56 and CD3 $\epsilon$ and lack of CD5; and genotype of the germ-line $T c R$ gene is currently acceptable for diagnosis of NK/T-cell lymphoma (Jaffe et al, 1996).

It should be noted that NK cells are developmentally closer to $\mathrm{T}$ cells than to other lymphoid cells (Denning et al, 1991; Lanier et al, 1992; Phillips et at, 1992; Spits et al, 1995). A novel developmental stage during fetal thymic ontogeny that delineates a population of T/NK-committed progenitors that express markers of NK1.1, cytoplasmic CD3, CD44, and CD117 has been identified (Carlyle et al, 1997). Among these markers, CD44 shows a trimodal distribution in lymphoid-cell ontogeny; it is strongly expressed in the earliest stages of development, suppressed at intermediate stages, and reexpressed at the later mature stages (Godfrey et al, 1993; Horst et al, 1990; Stauder et al, 1995). Recently, Chilosi et al reported a differentially high expression of cyclin-dependent kinase 6 (cdk6) in subcapsular thymocytes and T-cell lymphoblastic Iymphoma/leukemia (T-LBL/ALL) cells, but the absence of cdk6 in cells in most PTL of post-thymic genotype and phenotype (Chilosi et al, 1998). A strong nuclear cdk6 (n-cdk6) immunoreactivity seems to be associated with immature $T$ cells and T/NK-bipotent progenitors. Thus, phenotypic analysis of a combination of cdk6, CD3, CD44, CD56, and CD117, together with the study of rearrangement of the TcR gene may be used to highlight the stages of differentiation along the T/NK to T, or to NK, pathway (Carlyle et al, 1997).

In this study, we investigated the expression of the T/NK-cell markers cdk6, CD44, and CD117, which are developmentally differentially expressed, in 47 cases of NNP-NHL. We report abundant expression of n-cdk6, frequent absence of CD44, CD117, and TcR- $\gamma$ gene rearrangement in NK/Tcell lymphomas. We propose that CD56-positive NNP-NHL may represent a neoplasm of early T/NK bipotent progenitor cells with varying degrees of differentiation toward both immature NK cells and $T$ cells.

\section{Results}

\section{Pathologic Findings}

Among the 62 patients with NNP-NHL studied, 25 $(40.3 \%)$ were classified as NK/T-cell lymphomas. The lymphomas of 12 (19.4\%), 22 (35.5\%), and 3 (4.8\%) patients were classified as $\mathrm{CD}^{-} 6^{-}-\mathrm{T}$-cell $\mathrm{NHL}$ (or PTL), B-cell NHL, and T-LBL/ALL, respectively. NK/Tcell lymphomas were classified histologically as pleomorphic medium- and large-cell lymphomas (Fig. 1). Coagulative necrosis was seen in nearly all of these cases. Angioinvasion was present in eight cases (32\%).

PTL were composed of mixed medium and large tumor cells. Some of them showed pleomorphism (Fig. 1). The histopathology of PTL involving the nasal region is similar to that of $\mathrm{PTL}$ of nodal origin. In all cases, no definite angioinvasion was found. All B-cell lymphomas were classified as diffuse large cell lymphomas. The lymphoblastic lymphoma/leukemia cases showed a typical blastic appearance without necrosis.

\section{CD56 and TCR- $\gamma$}

A great majority $(92 \%$, cases \#1 to \#23) of NK/T-cell lymphomas was $\mathrm{CD}^{+}{ }^{+}$with a germ-line configuration of the $T c R-\gamma$ gene (Fig. 2). One case with the phenotype of $\mathrm{CD}^{-}{ }^{-} / \mathrm{CD}^{-}$(case \#24), had the germ-line $T c R-\gamma$ gene and was typical of NK/T-cell lymphoma, with polymorphism, angioinvasion, and coagulative necrosis. This case might fall in the category of CD56 NK/T-cell lymphoma. The remaining case (\#25), with the phenotype of $\mathrm{CD}^{+} 6^{+} / \mathrm{CD}^{+}$, had a rearranged $T c R-\gamma$ gene and had a histopathology in favor of NK/T-cell lymphoma.

PTL (case \#26 to \#37) was characterized by the presence of T-cell-associated markers (CD3 and CD45RO) and the absence of CD20 and CD56. Virtually all CD56- lymphomas showed clonal rearrangement of the $T c R-\gamma$ gene, which confirmed the diagnosis of PTL.

\section{cdk6, CD44, CD34, and CD117}

cdk6 was diffusely expressed in the nucleus and/or cytoplasm in up to $90 \%$ of neoplastic cells in the 25 cases of NK/T-cell lymphoma and in all 3 cases of T-LBL/ALL. When only nuclear expression was counted, 18 of the $25 \mathrm{NK} / \mathrm{T}$-cell lymphoma cases were immunoreactive in up to $90 \%$ of tumor cells (Fig. 1), and the remaining 7 cases were 30 to $50 \%$ immunoreactive. The three T-LBL/ALL had nuclear reactivity in up to $90 \%$ of tumor cells.

A variable intensity of cytoplasmic cdk6 immunoreactivity was present in most $\mathrm{CD}^{-} 6^{-} \mathrm{PTL}$, whereas nuclear immunoreactivity was present 30 to $50 \%$ and 10 to $30 \%$ of tumor cells in 2 cases each, predominantly in large pleomorphic tumor cells (Fig. 1). Six of the seven B-cell lymphomas had either faint or negative cytoplasmic immunoreactivity. One case had nu- 

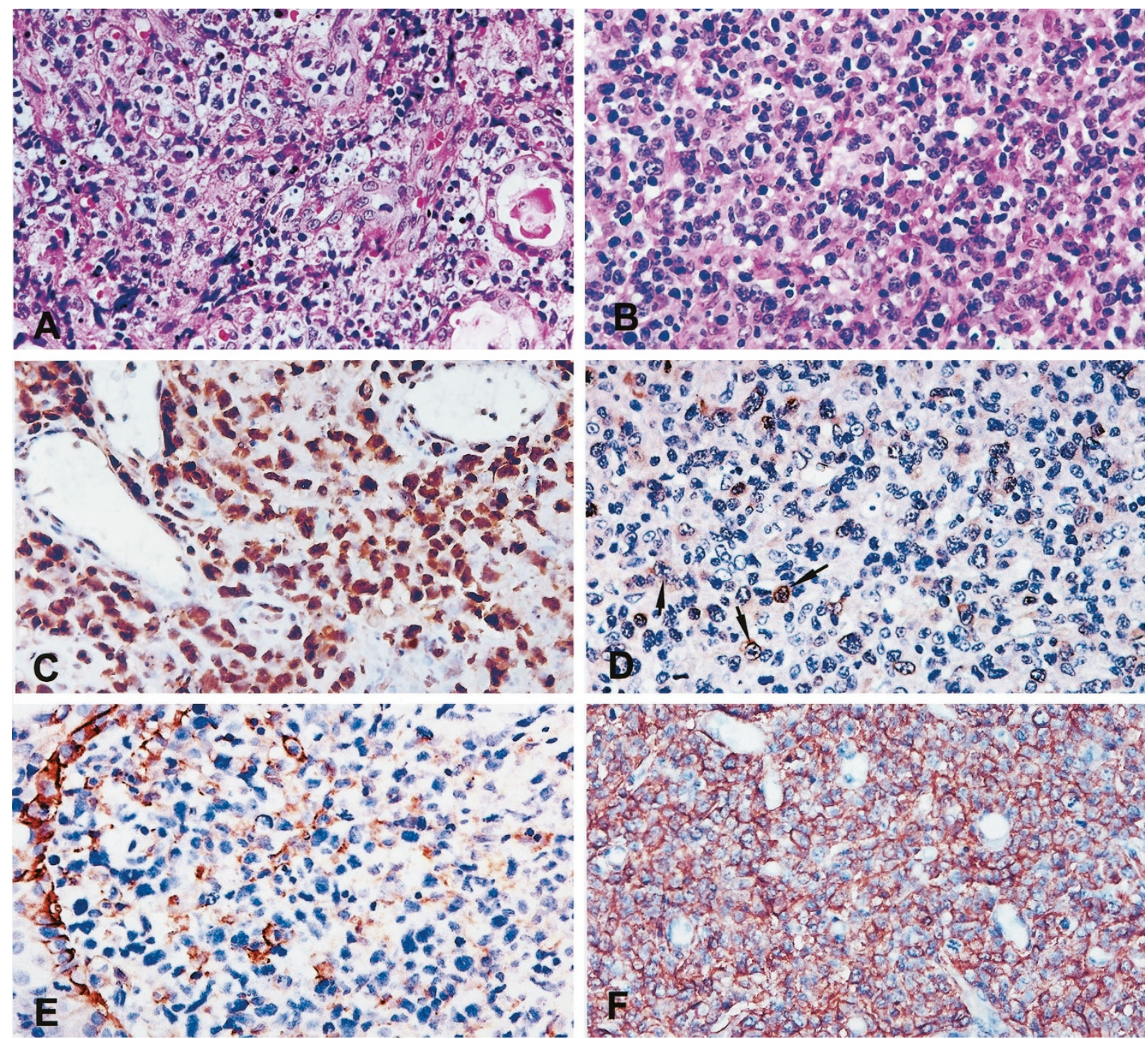

\section{Figure 1.}

Immunohistochemical analysis of cdk6 and CD44 in primary nasal/nasopharyngeal natural killer (NK)/T-cell lymphoma (A, C, and E) and peripheral T-cell lymphomas (PTL) (B, D, and F). A: NK/T-cell lymphoma shows pleomorphic infiltration composed of medium and large lymphoma cells exhibiting angioinvasion, angiodestruction and coagulative necrosis. B: PTL shows mixed medium and large lymphoma cells morphologically indistinguishable from those of NK/T-cell lymphoma cells. In contrast to the finding in NK/T-cell lymphomas, angiodestruction is not observed. C: Strong nuclear cdk6 immunoreactivity is present in 90 to $100 \%$ of NK/T-cell lymphoma cells. D: In contrast to NK/T-cell lymphoma, in PTL, cdk6 immunoreactivity is found predominantly in the cytoplasm of most tumor cells, whereas nuclear reactivity is absent. E: Almost all NK/T-cell lymphoma cells show negative CD44 immunoreactivity, whereas squamous epithelium, which acts as an internal control, is CD44-reactive. F: Compared to negative reactivity of CD44 in NK/T-cell lymphoma, the majority of PTL tumor cells exhibit strong reactivity of CD44.

clear immunoreactivity in the range of 10 to $30 \%$. These results agree with those of Chilosi et al (1998).

Nineteen of the $25(76 \%)$ NK/T-cell lymphomas and all of the 3 T-LBL/ALL were negative for CD44. Detection of CD44 in the squamous, pseudostratified, and/or columnar epithelium was used as a positive internal control (Orteu et al, 1997). Lymphoma cells in 9 of the 12 (75\%) PTL showed intense membranous immunoreactivity. The CD44 immunoreactivity was variable in the B-cell lymphomas; three cases were diffusely reactive, two cases were negative, and the remaining two cases showed faint immunoreactivity, not clearly above background. This is consistent with the findings of Horst et al (1990) and Stauder et al (1995).
Only one of the NK/T-cell lymphomas (case \#6) had membrane immunoreactivity for CD117 in large, pleomorphic tumor cells. Similar membrane immunoreactivity was also observed in subcapsular cortical thymocytes in human fetal thymus (data not shown). All NNP-NHL, including NK/T-cell lymphomas were CD34-

\section{EBV In Situ Hybridization Analysis}

In situ hybridization with the EBV encoded RNA-1 (EBER-1) probe revealed reactivity in most neoplastic cells; in all $25 \mathrm{NK} / \mathrm{T}$-cell lymphomas and in 9 (75\%) of the 12 PTL. None of the B-cell lymphomas or T-LBL/ ALL were EBER-1-reactive. 
Table 1. Summary for Clinical and Laboratory Data in Nasal NK/T Lymphoma and PTL

\begin{tabular}{|c|c|c|c|c|c|c|c|c|c|c|c|c|}
\hline & Age & Sex & $\mathrm{Cdk6}^{1}$ & CD44 & CD56 & $\operatorname{TCR} \gamma$ & CD45R0 & CD5 & CD8 & CD34 & CD117 & $\mathrm{EBV}^{2}$ \\
\hline \multicolumn{13}{|c|}{ NK/T Iymphoma } \\
\hline 1 & 49 & $f$ & ++ & + & + & G & + & - & + & - & - & + \\
\hline 2 & 58 & $\mathrm{~m}$ & +++ & - & + & G & + & - & - & - & - & + \\
\hline 3 & 56 & $\mathrm{~m}$ & +++ & - & + & G & + & - & - & - & - & + \\
\hline 4 & 69 & $\mathrm{~m}$ & +++ & - & + & G & + & - & - & - & - & + \\
\hline 5 & 28 & $\mathrm{~m}$ & ++ & - & + & G & - & - & - & - & + & + \\
\hline 6 & 60 & $\mathrm{~m}$ & +++ & - & + & G & - & - & - & - & - & + \\
\hline 7 & 48 & $\mathrm{~m}$ & +++ & \pm & + & G & + & - & - & - & - & + \\
\hline 8 & 44 & $\mathrm{~m}$ & +++ & - & + & G & - & - & - & - & - & + \\
\hline 9 & 44 & $\mathrm{~m}$ & +++ & - & + & G & - & - & - & - & - & + \\
\hline 10 & 31 & $\mathrm{~m}$ & +++ & + & + & G & + & - & ND & - & - & + \\
\hline 11 & 45 & $\mathrm{~m}$ & +++ & - & + & G & + & - & - & - & - & + \\
\hline 12 & 65 & $\mathrm{~m}$ & +++ & - & + & G & + & + & - & - & - & + \\
\hline 13 & 30 & $\mathrm{~m}$ & +++ & - & + & G & + & - & - & - & - & + \\
\hline 14 & 47 & $\mathrm{~m}$ & ++ & - & + & G & - & - & ND & - & - & + \\
\hline 15 & 68 & $\mathrm{~m}$ & ++ & - & + & G & + & - & - & - & - & + \\
\hline 16 & 78 & $\mathrm{~m}$ & +++ & - & + & G & + & + & - & - & - & + \\
\hline 17 & 66 & $\mathrm{~m}$ & ++ & + & + & G & + & - & - & - & - & + \\
\hline 18 & 57 & $\mathrm{~m}$ & ++ & - & + & G & + & - & - & - & - & + \\
\hline 19 & 60 & $\mathrm{~m}$ & +++ & + & + & G & + & - & - & - & - & + \\
\hline 20 & 48 & $\mathrm{~m}$ & +++ & - & + & G & + & - & - & - & - & + \\
\hline 21 & 44 & $\mathrm{~m}$ & +++ & - & + & G & + & - & - & - & - & + \\
\hline 22 & 58 & $\mathrm{~m}$ & +++ & - & + & G & + & - & - & - & - & + \\
\hline 23 & 61 & $\mathrm{~m}$ & +++ & - & + & G & + & - & - & - & - & + \\
\hline 24 & 34 & $\mathrm{~m}$ & +++ & + & - & G & + & - & - & - & - & - \\
\hline 25 & 57 & $\mathrm{~m}$ & ++ & + & + & $\mathrm{R}$ & + & + & - & - & - & - \\
\hline \multicolumn{13}{|c|}{ Peripheral T-cell lymphoma } \\
\hline 26 & 65 & f & - & - & - & ND & + & - & - & - & - & + \\
\hline 27 & 69 & $f$ & - & + & - & $\mathrm{R}$ & + & + & + & - & - & - \\
\hline 28 & 22 & $\mathrm{~m}$ & - & + & - & $\mathrm{R}$ & + & + & + & - & - & + \\
\hline 29 & 62 & $f$ & - & \pm & - & $\mathrm{R}$ & + & + & - & - & - & + \\
\hline 30 & 48 & $\mathrm{~m}$ & - & + & - & $\mathrm{R}$ & + & - & + & - & - & + \\
\hline 31 & 84 & $f$ & - & + & - & $\mathrm{R}$ & + & - & - & - & - & + \\
\hline 32 & 61 & $\mathrm{~m}$ & - & + & - & $\mathrm{R}$ & + & + & - & - & - & + \\
\hline 33 & 57 & $f$ & - & + & - & $\mathrm{R}$ & + & - & - & - & - & + \\
\hline 34 & 32 & $f$ & ++ & + & - & $\mathrm{R}$ & + & + & - & - & - & - \\
\hline 35 & 68 & $\mathrm{~m}$ & + & + & - & $\mathrm{R}$ & + & + & - & - & - & - \\
\hline 36 & 84 & $\mathrm{~m}$ & - & - & - & $\mathrm{R}$ & + & + & - & - & - & - \\
\hline 37 & 38 & $f$ & + & + & - & $\mathrm{R}$ & + & + & - & - & - & + \\
\hline
\end{tabular}

* TCR $\gamma$, T-cell receptor $\gamma$ gene; G, germline; R, rearranged; ND, not done.

${ }^{1}$ Quantitative evaluation of nuclear CDK6 expression: - , $0-10 \%,+, 10-30 \% ;++, 30-50 \%$; +++, $50-100 \%$. Evaluation for other antigen expression: \pm , faint, not clearly above background; - , negative; + , positive staining.

${ }^{2}$ EBV: EBER-1 (EBV encoded RNA-1).

\section{Discussion}

There is uncertainty regarding the true nature of NK/T nasal lymphoma, although several studies favor an NK-cell origin (Chiang et al, 1996,1997). Based on a number of phenotypic, ontogenetic, and functional analyses, NK cells are developmentally closer to T cells than are other lymphoid cells (Denning et al, 1991; Lanier et al, 1992; Phillips et al, 1992; Spits et al, 1995). These studies show: 1 ) the presence of CD3 $\epsilon$, $\gamma, \delta$, and $\zeta$ in fetal NK cells and the presence of CD3 $\epsilon$ in activated adult NK cells; 2) the origin of T and NK cells from common precursors expressing $\mathrm{CD} 3 \epsilon$, CD44, CD56, and CD117; 3) the cloning of NK cells from triple-negative thymocytes; and 4) the cytotoxic function shared by $T$ and NK cells. Although markers specific for a T/NK bipotential progenitor have not been identified, a combination of cytoplasmic CD3, CD44, CD56, and CD117 may be used to highlight the stages of differentiation along the T/NK to $T$ or NK pathways (Carlyle et al, 1997).

As previously described, cdk6 may also be added to this panel for evaluation of T/NK-cell maturation. $\mathrm{N}$-cdk6 is differentially expressed in a discrete portion of subcapsular cortical thymocytes, but not in medullary thymocytes or in mature T cells. Not unexpectedly, the expression of n-cdk6 was usually absent in NHL (Chilosi et al, 1998) and also absent in large granular lymphocytes of true NK-cell type expressing 

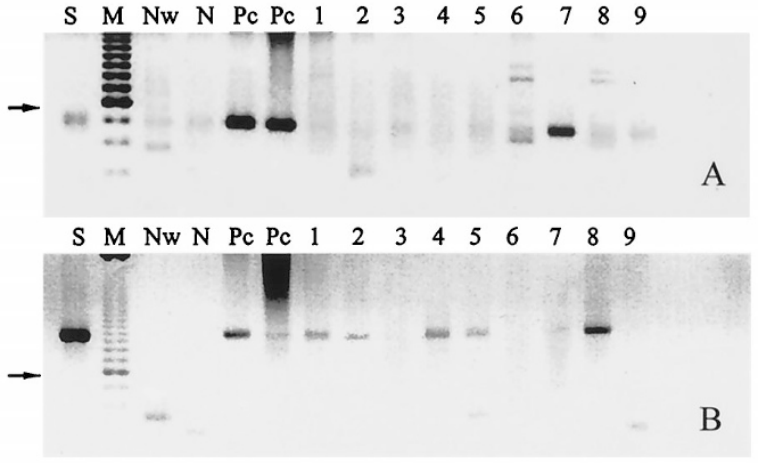

Figure 2.

Monoclonality (gene rearrangement) of the $T c R-\gamma$ gene in PTL. Agarose gel $(3 \%)$ analysis of $T c R-\gamma$ PCR products was performed. Three primer sets were used separately in the PCR reaction. The expected size of the rearranged $T C R-\gamma$ gene is 70 to $95 \mathrm{bp}$ for primer set [Vrl + Vrlll/iv + Jr1/2] (A), 80 to $110 \mathrm{bp}$ for primer set [Vrl + Vrlll/iv + JPr1/2] (data not shown), and 150 to $180 \mathrm{bp}$ for primer set [Vrll + Jr1/2] (B). M, 20-base-pair marker; Nw, negative control (water only); $N$, negative control for PCR from a case diagnosed as follicular lymphoma; PC, positive control for PCR from cases diagnosed as T-cell lymphoma; lanes 1, 2, 4, 5, 7, and 8, PTL; lanes 3, 6, and 9, nasal T/NK cell lymphoma.

mature phenotypes $\left(\mathrm{CD} 16^{+} / \mathrm{CD} 57^{+}\right)$and genotypes (unpublished data). In this study, we noted strong $\mathrm{n}$-cdk6 expression in most tumor cells of virtually all examined cases of NK/T-cell lymphoma and T-LBL/ ALL. N-cdk6 reactivity was observed only in a small number of large polymorphic tumor cells in 3 of 12 cases of PTL involving the nasal region. A strong n-cdk6 immunoreactivity seems to be associated with T/NK progenitor cells or $\mathrm{T}$ cells in early stages of maturation and/or differentiation.

In this study, we noted the absence of CD44 in the majority of cases of NK/T-cell lymphoma, whereas expression of CD44 was a common finding in PTL. CD44, a heavily glycosylated adhesion molecule, has been shown to be involved in hematopoiesis, lymphocyte activation and homing, tumor metastasis, and cytolytic effects through cell-cell and cell-matrix interactions (Günthert et al, 1993; Haynes et al, 1989; Herrlich et al, 1993; Lesley et al, 1993; Tan et al, 1993). CD44 shows a characteristic trimodal distribution in lymphoid-cell ontogeny, being strongly expressed in the earliest stages of development, suppressed at the stage of cortical thymocytes, and re-expressed at the later mature stages (ie, medullary thymocytes and peripheral T cells). As expected, CD44 is expressed in virtually all NHL, including PTL (Horst et al, 1990; Orteu et al, 1997; Sauder et al, 1995).

Among NK cells, CD44 is constitutively expressed by early T/NK progenitors (Carlyle et al, 1997) and peripheral-blood mature NK cells $\left(\mathrm{CD} 16^{+}\right.$) (Delfino et al, 1994; Mäenpää et al, 1993). CD44 is detected in large granular lymphocytic leukemia of NK-cell lineage, which is phenotypically characterized by $\mathrm{CD} 6^{+} / \mathrm{CD} 16^{+} / \mathrm{CD} 4^{-} / \mathrm{CD}^{-}$(unpublished data). The absence of CD44 and expression of n-cdk6 in NK/Tcell lymphoma cells seems to underscore a distinction of this lymphoma from PTL and large granular lymphocytes of true NK-cell type of mature phenotype.
The mechanism underlying overexpression of n-cdk6 is currently unknown. In this study, we detected EBV infection in $100 \%$ of NK/T-cell lymphomas. The EBV-encoded proteins (eg, EBNA-2) have been shown to exert transforming activity by upregulation of a number of cdk (including cdk6) and cyclins, downregulation of a subset of cdk inhibitors, and indirect regulation of the phosphorylation status of retinoblastoma gene product $(\mathrm{Rb})$ (Cannell et al, 1996; Parker et al, 1996; Sinclair et al, 1994). Nevertheless, the abundant expression of n-cdk6 in NK/T-cell lymphomas cannot be attributed entirely to EBV infection, inasmuch as EBV-positive nasal PTL were n-cdk6negative. cdk6 and cdk4 couple with D-type cyclins to form holoenzymes whose activities, by phosphorylating $\mathrm{Rb}$ and its related proteins, are both necessary and rate-limiting for $G_{1}$ progression (Ewen et al, 1993; Meyerson and Harlow, 1994; Sherr, 1993). We detected the abundant presence of hyperphosphorylated $\mathrm{Rb}$ in three cases of T/NK cell lymphoma, but not in the two cases of nasal PTL examined (data not shown). Disregulation and/or overexpression of cdk6 and the subsequent phosphorylation of Rb may play important roles in the pathogenesis of NK/T-cell lymphoma.

Combined with the expression of cytoplasmic CD3 and the lack of Tdt, CD1, CD16, CD44, CD57, CD117, and TcR-GR, cells in NK/T-cell lymphomas might be regarded to have differentiated phenotypically beyond the bi-potential NK/T progenitor cell stage, but to have not reached the mature T-cell stage (surface $\mathrm{CD}^{+}$/ $\left.T c R-\mathrm{GR}^{+}\right)$or mature NK-cell $\left(\mathrm{CD} 16^{+} / \mathrm{CD} 57^{+}\right)$stage (Carlyle et al, 1997; Delfino et al, 1994; Mäenpää et al, 1993). Cells in NK/T-cell lymphomas might be derived from mature NK cells that have an aberrant phenotype, caused by its dedifferentiated state and/or infection by EBV. Alternatively, these NK/T-cell lymphomas may represent neoplasms of T/NK-cell common progenitors or immature NK-cell precursors with varying degrees of differentiation (Suzumiya et al, 1994), with some of them acquiring certain T-cell-related antigens. This speculation is not without merit. Several recent studies have suggested that a number of mature-looking neoplastic cells originated from, or are related to, immature precursors or even early progenitor cells (eg, CD34 ${ }^{+}$hematopoietic stem cells). Examples where this occurs include B-cell chronic lymphocytic leukemia (Gahn et al, 1997), plasma cell myeloma (Arpin et al, 1998), Hodgkin's disease (Hsu et al, 1996), chronic myelogenous leukemia, and other related myeloproliferative diseases (Vardiman, 1992).

It is a conventional dogma that neoplastic cells represent cells capable of proliferation and dedifferentiation that are arrested at certain stages of maturation. However, some neoplasms might be related to early progenitors capable of maturation or differentiation, with flawed, incomplete or directionless abilities to differentiate.

Patients with nasal NK/T-cell lymphoma may have systemic skin, liver, spleen, and bone marrow involvement (ie, so-called aggressive NK-cell leukemia/lymphoma) (Chan et al, 1997; Tsuchiyama et al, 1998). 
Interestingly, all these cases of aggressive NK-cell leukemia $\left(\mathrm{EBV}^{+}\right)$presented a phenotype similar to that of classical NK/T-cell lymphoma. This form of aggressive NK-cell leukemia is different from a chronic form of large granular lymphocytic leukemia of mature NK-cell phenotype $\left(\mathrm{CD} 16^{+} / \mathrm{CD} 57^{+}\right)$both clinically and phenotypically. One should also note that cases of lymphoblastic lymphoma $\left(\mathrm{CCD}^{+} / \mathrm{CD} 6^{+} / \mathrm{CD}^{+} /\right.$ $\mathrm{CD}^{-} / \mathrm{CD}^{-} 7^{-} / \mathrm{TCR}-\mathrm{GR}^{-}$) derived from bipotent progenitors committed to NK-cell differentiation have been reported (Chan et al, 1997; Ichinohasama et al, 1996; Koiwai, 1995; Tamura et al, 1998). Furthermore, blastoid or blastic NK-cell lymphoma resembling lymphoblastic lymphoma (LBL) has also been found (Chan et al, 1997; Kobashi et al, 1996). The genotypes and phenotypes of CD56 \pm lymphoblastic lymphoma, blastoid NK-cell lymphoma, and classical NK/T-cell lymphoma/leukemia are very similar, if not identical. However, CD56 \pm lymphoblastic lymphoma and blastoid-NK cell lymphoma are generally EBVnegative, whereas classical NK/T-cell lymphoma/leukemia is often EBV-positive.

\section{Materials and Methods}

\section{Patient Samples}

Sixty-two cases of primary NNP-NHL were reviewed from the files of the Department of Pathology at National Taiwan University Hospital during the interval between 1988 and 1998. All biopsy samples were obtained without prior therapy. All were formalin-fixed and paraffin-embedded except in five cases, in which snap-frozen specimens were also available. Among these 62 cases, 15 classified as B-cell lymphoma were not included in further phenotypic and genotypic studies.

\section{Immunohistochemistry}

Five-micron sections of paraffin-embedded tissue were dewaxed, rehydrated, and immersed in sodium citrate buffer, $\mathrm{pH}$ 6.0. The sections were treated in a standard domestic microwave oven for 10 minutes at the maximum power setting. Sections were then left to cool for 20 minutes at room temperature before being transferred to $0.5 \% \mathrm{H}_{2} \mathrm{O}_{2}$ for blocking of endogenous peroxidases, then washed with PBS buffer. An avidinbiotin-peroxidase complex method (Vector Laboratory, Burlingame, California) was used for monoclonal and polyclonal antibody immunoreactivity.

Immunoreactivity for cdk6 was performed with an affinity-purified rabbit polyclonal antibody that recognizes a peptide corresponding to amino-acid residues 306 to 326, mapping at the carboxyl terminus of cdk6 (C-21, Santa Cruz Biotechnology, Santa Cruz, California). Immunoreactivity for CD44 was performed with a monoclonal antibody, anti-human CD44H (2C5/lgG2a subclass, R\&D Systems Ltd., Minneapolis, Minnesota), that recognizes all CD44 isoforms, including the standard CD44 isoform (CD445). Additional panels of antibodies used are as follows: CD3€ (polyclonal), CD8, CD20, CD45RO (Dako SA, Glostrup, Denmark), CD117 (MBL Company Ltd., Nagoya, Japan), CD5, CD56 (Novocastra Lab Ltd., Newcastle, United Kingdom), and CD34 (BioGenex, San Ramon, California).

Quantitative evaluation of cdk6 expression was performed by counting the percentage of positively immunoreactive cells in high-power $(\times 40)$ microscopic fields. The percentages of tumor cells expressing nuclear cdk6 were defined as follows:,$-<10 \% ;+, 10$ to $30 \%$; ++, 30 to $50 \%$; and,+++ 50 to $100 \%$.

\section{In Situ Hybridization Analysis}

Lymphoma sections were deparaffinized and digested with proteinase K (Sigma Chemical Corporation, St. Louis, Missouri) before being hybridized with digoxigenin-labeled oligonucleotide probes (30 base pairs) for EBER-1 RNA antisense sequences. The washed sections were then reacted with an antidigoxigenin alkaline-phosphatase-conjugated antibody (Boehringer Mannheim, Bedford, Massachusetts) and developed with the nitroblue-tetrazolium chloride/5-bromo-4-chloro-3-indolyl-phosphate substrate.

\section{T-cell Receptor $\gamma$ Rearrangement Study}

Genomic DNA was extracted from paraffin-embedded tissue blocks with QIAamp kits (QIAGEN, Valencia, California). The $T c R-\gamma$-chain gene was examined by PCR as described by Diss et al (1995). Briefly, three sets of primers, $\mathrm{Vrl}+\mathrm{Vrlll} / \mathrm{iv}+\mathrm{Jr} 1 / 2$ (product size approximately 70 to 95 base pairs), $\mathrm{Vrl}+\mathrm{Vrlll} / \mathrm{iv}+\mathrm{Jpp} 1 / 2$ (product size approximately 80 to 110 base pairs), and Vrll+Jr1/2 (product size approximately 150 to 180 base pairs) were used separately in total volumes of $40 \mu \mathrm{l}$ of reaction mixture, which contained $10 \mathrm{~mm}$ Tris- $\mathrm{HCl}(\mathrm{pH} 8.8), 1.5$ $\mathrm{mm} \mathrm{MgCl}_{2}, 50 \mathrm{~mm} \mathrm{KCl}, 0.1 \%$ Triton X-100, $200 \mu \mathrm{M}$ of each dNTP, $1 \mathrm{~mm}$ of each primer, $100 \mathrm{ng}$ of DNA, and 1 unit of Taq polymerase. The primer sequences were as follows: Vrl, 5'-TCTGGG/AGTCTATTACTGTGC-3'; Vrlll/iv, 5'-CTCACACTCC/TCACTTC-3'; Jr1/2, 5'CAAGTGTTGTTCCACTGCC-3'; Jpr1/2, 5'-GTTACTA TGAGCT/CTAGTC-3'; and Vrll, 5'-GAAAGGAATCT GGCATTCCG-3' . The reaction mixture was subjected to 40 cycles of PCR after an initial 2-minute denaturation step at $94^{\circ} \mathrm{C}$. Each cycle consisted of denaturation at $94^{\circ} \mathrm{C}$ for 30 seconds, annealing at $55^{\circ} \mathrm{C}$ for 30 seconds, and extension at $72^{\circ} \mathrm{C}$ for 45 seconds. Ten microliters of PCR-amplified product was resolved by electrophoresis on 3\% agarose gel. All samples were studied in duplicate.

\section{Acknowledgements}

The authors thank Dr. Chun Hsu for review of the clinical history of the patients enrolled in this study. This work was supported by grants NSC 89-2314-B002-089 and NHRI-GT-EX89S704L. 


\section{References}

Arber DA, Weiss LM, Albujar RF, Chen YY, and Jaffe ES (1993). Nasal lymphoma in Peru, high incidence of T-cell immunophenotype and Epstein-Barr virus infection. Am J Surg Pathol 17:392-399.

Arpin C, de Bouteiller O, Razanajaona D, Fugier-Vivier I, Briere F, Banchereau J, Lebecque S, and Liu YJ (1998). The normal counterpart of IgD myeloma cells in germinal center displays extensively mutated IgVH gene, $\mathrm{C} \mu-\mathrm{C} \delta$ switch, and lambda light chain expression. J Exp Med 187:1169-1178.

Cannell EJ, Farrell PJ, and Sinclair AJ (1996). Epstein-Barr virus exploits the normal cell pathway to regulate $\mathrm{Rb}$ activity during the immortalisation of primary B-cells. Oncogene 13:1413-1421.

Carlyle JR, Michie AM, Furlonger C, Nakano T, Lenardo MJ, Paige CJ, and Zúñiga-Pflücker JC (1997). Identification of a novel developmental stage marking lineage commitment of progenitor thymocytes. J Exp Med 186:173-182.

Chan JKC, Ng CS, Lau WH, and Lo STH (1987). Most nasal/nasopharyngeal lymphomas are peripheral T-cell neoplasms. Am J Surg Pathol 11:418-429.

Chan JK, Sin VC, Wong KF, Ng CS, Tsang WY, Chan CH, Cheung MM, and Lau WH (1997). Nonnasal lymphoma expressing the natural killer cell marker CD56: A clinicopathologic study of 49 cases of an uncommon aggressive neoplasm. Blood 89:4501-4513.

Chiang AKS, Chan ACL, Srivastava G, and Ho FCS (1997). Nasal T/Natural killer (NK)-cell lymphomas are derived from Epstein-Barr virus-infected cytotoxic lymphocytes of both NK- and T-cell lineage. Int J Cancer 73:332-338.

Chiang AKS, Srivastava G, Lau PWF, and Ho FCS (1996). Differences in T-cell-receptor gene rearrangement and transcription in nasal lymphomas of natural killer and T-cell types: Implications on cellular origin. Hum Pathol 27:701707.

Chilosi M, Doglioni C, Yan Z, Lestani M, Menestrina F, Sorio C, Benedetti A, Vinante F, Pizzolo G, and Inghirami G (1998). Differential expression of cyclin-dependent kinase 6 in cortical thymocytes and T-cell lymphoblastic lymphoma/ leukemia. Am J Pathol 152:209-217.

Delfino DV, Patrene KD, DeLeo AB, DeLeo R, Herberman RB, and Boggs SS (1994). Role of CD44 in the development of natural killer cells from precursors in long-term cultures of mouse bone marrow. J Immunol 152:5171-5179.

Denning SM, Jones DM, Ware RE, Weinhold KJ, Brenner MB, and Haynes BF (1991). Analysis of clones derived from human $\mathrm{CD}^{+} \mathrm{CD} 4^{-} \mathrm{CD} 8^{-} \mathrm{CD} 3^{-}$thymocytes. Int Immunol 3:1015-1024.

Diss TC, Watts M, Pan LX, Burke M, Linch D, and Isaacson $P G$ (1995). The polymerase chain reaction in the demonstration of monoclonicity in $\mathrm{T}$ cell lymphomas. $\mathrm{J}$ Clin Pathol 48:1045-1050.

Elenitoba-Johnson KS, Zarate-Osorno A, Meneses A, Krenacs L, Kingma DW, Raffeld M, and Jaffe ES (1998). Cytotoxic granular protein expression, Epstein-Barr virus strain type, and latent membrane protein-1 oncogene deletions in nasal T-lymphocyte/natural killer cell lymphomas from Mexico. Mod Pathol 11:754-761.

Emile J-F, Boulland M-L, Haioun C, Kanavaros P, Petrella T, Delfau-Larue M-H, Bensussan A, Farcet J-P, and Gaulard P
(1996). CD5 ${ }^{-} \mathrm{CD}^{+} 6^{+}$T-cell-receptor silent peripheral T-cell lymphomas are natural killer cell lymphomas. Blood 87: 1466-1473.

Ewen ME, Sluss HK, Sherr CJ, Matsushime H, Kato J, and Livingston DM (1993). Functional interactions of the retinoblastoma protein with mammalian D-type cyclins. Cell 73: 487-497.

Gahn B, Schäfer C, Neef J, Troff C, Feuring-Buske M, Hiddemann W, and Wörmann B (1997). Detection of trisomy 12 and Rb-deletion in $\mathrm{CD} 34^{+}$cells of patients with B-cell chronic lymphocytic leukemia. Blood 89:4275-4281.

Gaulard P, Henni T, Marolleau J-P, Haioun C, Henni Z, Voisin M-C, Divine M, Goossens M, Farcet J-P, and Reyes F (1988). Lethal midline granuloma (polymorphic reticulosis) and lymphomatoid granulomatosis. Evidence for a monoclonal T-cell lymphoproliferative disorder. Cancer 62:705-710.

Godfrey DI, Kennedy J, Suda T, and Zlotnik A (1993). A developmental pathway involving four phenotypically and functionally distinct subsets of $\mathrm{CD} 3^{-} \mathrm{CD} 4^{-} \mathrm{CD} 8^{-}$triplenegative adult mouse thymocytes defined by CD44 and CD25 expression. J Immunol 150:4244-4252.

Günthert U (1993). CD44: A multitude of isoforms with diverse functions. Curr Top Microbiol Immunol 184:47-62.

Haynes BF, Telen MJ, Hale LP, and Denning SM (1989). CD44-, a molecule involved in leukocyte adherence and T-cell activation. Immunol Today 10:423-428.

Herrlich P, Zoller M, Pals ST, and Ponta H (1993). CD44 splice variants: Metastases meet lymphocytes. Immunol Today 14:395-399.

Ho FCS, Choy D, Loke SL, Kung ITM, Fu KH, Liang R, Todd D, and Khoo RKK (1990a). Polymorphic reticulosis and conventional lymphomas of the nose and upper aerodigestive tract: A clinicopathologic study of 70 cases, and immunophenotypic studies of 16 cases. Hum Pathol 21:10411050.

Ho FCS, Srivastava G, Loke SL, Fu KH, Leung BPY, Liang R, and Choy D (1990b). Presence of Epstein-Barr virus DNA in nasal lymphomas of $B$ and $T$ cell type. Hematol Oncol 8:271-281.

Ho FCS, Todd D, Loke SL, Ng RP, and Khoo RKK (1984). Clinico-pathological features of malignant lymphomas in 294 Hong Kong Chinese patients; retrospective study covering an eight-year period. Int J Cancer 34:143-148.

Horst E, Meijer CJLM, Radaskiewicz T, van Dongen JJM, Pieters R, Figdor CG, Hooftman A, and Pals ST (1990). Expression of a human homing receptor (CD44) in lymphoid malignancies and related stages of lymphoid development. Leukemia 4:383-389.

Hsu SM, Waldron AJ Jr, Xie SS, and Hsu PL (1996). Hodgkin's disease and anaplastic large cell lymphoma revisited - II. From cytokines to cell lineage. J Biomed Sci 3:1-13.

Ichinohasama R, Endoh K, Ishizawa K, Okuda M, Kameoka J, Meguro K, Myers J, Kadin ME, Mori S, and Sawai T (1996). Thymic lymphoblastic lymphoma of committed natural killer cell precursor origin: A case report. Cancer 77:2592-2603.

Jaffe ES (1995). Nasal and nasal-type NK/T-cell lymphoma: A unique form of lymphoma associated with the Epstein-Barr virus. Histopathology 27:581-583.

Jaffe ES (1996). Classification of natural killer (NK) cell and NK-like T-cell malignancies. Blood 87:1207-1210. 
Jaffe ES, Chan JKC, Su IJ, Frizzera G, Mori S, Feller AC, and Ho FCS (1996). Report on the workshop on nasal and related extranodal angiocentric T/natural killer cell lymphomas. Am J Surg Pathol 20:103-111.

Jaffe ES, Lipford EH, Margolick JB, Longo DL, and Fauci AS (1989). Lymphomatoid granulomatosis and angiocentric lymphoma: A spectrum of post-thymic T-cell proliferations. Semin Respir Med 10:167-172.

Kanavaros P, Lescs MC, Briere J, Divine M, Galateau F, Joab I, Bosq J, Farcet JP, Reyes F, and Gaulard P (1993). Nasal T-cell lymphoma: A clinicopathologic entity associated with peculiar phenotype and with Epstein-Barr virus. Blood 81: 2688-2695.

Kobashi Y, Nakamura S, Sasajima Y, Koshikawa T, Yatabe Y, Kitoh K, Mori S, Ueda R, Yamabe H, and Suchi T (1996). Inconsistent association of Epstein-Barr virus with CD56 (NCAM)-positive angiocentric lymphoma occurring in sites other than the upper and lower respiratory tract. Histopathol 28:111-120.

Koiwai O (1995). Novel leukemic lymphoma with probable derivation from immature stage of natural killer (NK) lineage in an aged patient. Hematol Oncol 13:1-11.

Lanier LL, Chang C, Spits H, and Phillips JH (1992). Expression of cytoplasmic $\mathrm{CD} 3 \epsilon$ proteins in activated human adult NK cells and CD $3 \gamma, \delta, \epsilon$ complexes in fetal NK cells: Implications for the relationship of NK and T lymphocytes. J Immunol 14:1876-1880.

Lesley J, Hyman R, and Kincade PW (1993). CD44 and its interaction with the extracellular matrix. Adv Immunol 54: 271-335.

Mäenpää $A$, Jääskeläinen $J$, Carpén $O$, Patarroyo $M$, and Timonen T (1993). Expression of integrins and other adhesion molecules on NK cells: Impact of IL-2 on short- and longterm cultures. Int J Cancer 53:850-855.

Meyerson $M$ and Harlow ED (1994). Identification of $G_{1}$ kinase activity for cdk6, a novel cyclin D partner. Mol Cell Biol 14:2077-2086.

Mori N, Yatabe Y, Oka K, Kinoshita T, Kobayashi T, Ono T, and Asai J (1996). Expression of perforin in nasal lymphoma: Additional evidence of its natural killer cell derivation. Am J Pathol 149:699-705.

Ng CS, Lo STH, Chan JKC, and Chan WC (1997). CD56 ${ }^{+}$ putative natural killer cell lymphomas: Production of cytolytic effectors and related proteins mediating tumor cell apoptosis? Hum Pathol 28:1276-1282.
Orteu CH, Li W, Allen MH, Smith NP, Barker JN, and Whittaker SJ (1997). CD44 variant expression in cutaneous T-cell lymphoma. J Cutan Pathol 24:342-349.

Parker GA, Crook T, Bain M, Sara EA, Farrell PJ, and Allday MJ (1996). Epstein-Barr virus nuclear antigen (EBNA) $3 C$ is an immortalizing oncoprotein with similar properties to adenovirus E1A and papillomavirus E7. Oncogene 13:2541-2549.

Phillips JH, Hori T, Nagler A, Bhat H, Spits H, and Lanier LL (1992). Ontogeny of human natural killer cells: Fetal NK cells mediate cytolytic function and express cytoplasmic $\mathrm{CD} 3 \epsilon, \delta$ proteins. J Exp Med 175:1055-1066.

Sherr CJ (1993). Mammalian $G_{1}$ cyclins. Cell 73:1059-1065.

Sinclair AJ, Palmero I, Peters G, and Farrell PJ (1994). EBNA-2 and EBNA-LP cooperate to cause $G_{0}$ to $G_{1}$ transition during immortalization of resting human $B$ lymphocytes by Epstein-Barr virus. EMBO 13:3321-3328.

Spits H, Lanier LL, and Phillips JH (1995). Development of human T and natural killer cells. Blood 85:2654-2670.

Stauder R, Eisterer W, Thaler J, and Günthert U (1995). CD44 variant isoforms in non-Hodgkin's lymphoma: A new independent prognostic factor. Blood 85:2885-2899.

Suzumiya J, Takeshita M, Kimura N, Kikuchi M, Uchida T, Hisano S, Eura Y, Kozuru M, Nomura Y, Tomita K, Komiyama S, and Okumura M (1994). Expression of adult and fetal natural killer cell markers in sinonasal lymphomas. Blood 83:2255-2260.

Tamura H, Ogata K, Mori S, An E, Tajika K, Sugisaki Y, and Dan K (1998). Lymphoblastic lymphoma of natural killer cell origin, presenting as pancreatic tumour. Histopathol 32:508511.

Tan PHS, Santos EB, Rossbach HC, and Sandmaier BM (1993). Enhancement of natural killer activity by an antibody to CD44. J Immunol 150:812-820.

Tsuchiyama J, Yoshino T, Mori M, Kondoh E, Oka T, Akagi T, Hiraki A, Nakayama H, Shibuya A, Ma Y, Kawabata T, Okada $S$, and Harada M (1998). Characterization of a novel human natural killer-cell line (NK-YS) established from natural killer cell lymphoma/leukemia associated with Epstein-Barr virus infection. Blood 92:1374-1383.

Vardiman JW (1992). Chronic myelogenous leukemia and the myeloproliferative disorders. In: Knowles DM, editor. Neoplastic Hematopathology. Baltimore: Williams \& Wilkins, 1405-1438. 